\title{
Kamu Yönetimi Disiplininin Kökenleri: Prusya Ekolü
}

\author{
The Origins of Public Administration Discipline: Prussia School
}

\author{
Ali RIza SAKLI ${ }^{1}$
}

\begin{abstract}
ÖZET
Kamu yönetimi disiplininin ABD'de doğduğu ve Wilson'la başladığı biçimindeki yaygın kanaatin doğru olmadığı, disiplinin Fransa ve Almanya'daki çalışmalarla hayat bulduğu anlaşımıştır. Wilson yaklaşımının siyaset-yönetim ayrımını getirdiği ve kamu yönetimini işletme disiplinine yaklaştırarak, kimlik bunalımına soktuğu tespitlerine karşılık, Avrupa kamu yönetimi yaklaşımlarında siyaset-yönetim ayrımının zaten mevcut olduğu belli olmuştur. Ancak, kamu yönetiminin işletme disipliniyle özdeşleştirilmesinin Wilson'a ait bir vurgu olduğu kanaatine varılmıştır. Prusya kamu yönetimi ekolü ele alınarak; Seckendorff, Wolff, Hegel ve Lorenz Von Stein'in savundukları görüşlere yer verilmiştir. Ayrıca, Wilson'un dayandığı Alman Bluntschli'nin görüşleri Türk alan yazınında ilk defa olarak ele alınmıştır.
\end{abstract}

Anahtar Kelimeler: Kamu yönetiminin kökeni, Prusya kamu yönetimi ekolü, kameralizm, bluntschli, wilson.

\section{GiRiş}

Kamu yönetimi, yönetim faaliyetinin kamu örgütleri bakımından ele alınması olarak kabul edilebilir. Yönetim; 'amaçlara ulaşmak için maddi ve sosyal kaynakları belli bir plân ve örgütsel yapı dâhilinde harekete geçirmek' olarak tanımlanırsa, kamu amaçlarını gerçekleştirmek için girişilen yönetim faaliyeti, kamu yönetimi olarak değerlendirilebilir.

Toplumun ortak işlerinin birlikte görülmesi, kamu yönetiminin tarihsel başlangıcını oluşturur. Devletlerin gelişimi ve zaman içerisinde kamu görevi olarak kabul edilen konuların kapsam ve içerik olarak genişlemesi ile devlet yönetimine yönelik bilgiler ve eserler ortaya çıkmaya başlamıştır. Devlet yönetimine ilişkin ilk çalışmalarda, devletin bir bütün olarak ele alındığı; siyaset, hukuk ve yönetim arasında ayrım yapılmadığı bilinmektedir.

Kamu yönetiminin bağımsız bir alan olarak ortaya çıkışı, siyaset ve hukuktan ayrışması ile mümkün olmuştur. Disiplinin hukuktan ayrışması, Montesquieu'nun kuvvetler ayrılığı ilkesinin etkisiyle gelişmiştir. Siyaset biliminden ayrışması ise, kamu yönetiminin bağımsız bir disiplin olarak ortaya çıkışı-

\begin{abstract}
The studies revealed that the discipline of the public administration was born in France and Germany, on the contrary of common and incorrect belief that it was born in the United States and it began with Wilson. It has been defined that the separation of politics-administration already exists in the European public administration approaches, but the emphasis on the conceding of public administration and business discipline as identical, belongs to Wilson. By considering the Prussian school of public administration; concepts of Seckendorff, Wolff, Hegel and Lorenz von Stein are reported shortly. In addition, German Bluntschli, which Wilson expresses his opinions depends on him, first time evaluated in Turkish literature of the field.
\end{abstract}

Keywords: The origin of public administration, public administration school of Prussia, kameralizm, bluntschli, wilson.

nın miladı olarak kabul edilmiştir. Bu kabulde önemli bir oydaşma var olmakla birlikte, ayrışmanın nerede meydana geldiği ve kim tarafından ortaya atıldığı ile ilgili bilgiler giderek farklılaşmaktadır.

Kamu yönetimi disiplininin, Woodrow Wilson'un yaptığı siyaset-yönetim ayrımıyla ABD'de doğduğu ve oradan Avrupa'ya aktarıldığı şeklinde, alan yazınında geniş kabul gören bir yaklaşım mevcuttu. Yapılan yeni araştırma ve değerlendirmeler, bu bilgilerin doğru olmadığını ortaya koymaktadır. Disiplinin ABD'de kurucusu sayılan Wilson'dan (1887) önce, Fransa ve Almanya'da geliştiği ve sonra okyanus ötesine geçtiği belirgin bir biçimde ortaya çıkmaktadır.

Kamu yönetiminin kökeninin Avrupa'ya veya ABD'ye dayalı olmasının ne gibi bir önemi vardır? Her şeyden önce, iki kıtaya ait farklı kamu yönetimi anlayışları olduğu, bu sebeple disiplinin ortaya çıktığı noktada sahip olduğu özelliklerin ve öncüllerinin neler olduğu önemli görülmektedir.

Nitekim Wilson (1887:202), disiplinin Avrupa'da doğduğunu ve oraya ait olduğunu, bu nedenle süratle Amerikanlaştırılması gerektiğini ifade etmiştir. Bunun gerekçesi olarak da, Avrupa devlet sisteminin 
merkeziyetçi yapıya sahip olduğunu belirterek, bu tür bir devlet için geliştirilmiş olan kamu yönetiminin federal yapıdaki ABD'ye uyumlaştırılması gereğinden bahsetmiş̧tir.

Waldo'nun (1968), kamu yönetiminin bunalımda olduğunu ilan ettiğinden beri yapılan tartışmalarda, bunalımın nedeni olarak; Wilson'la başlayan ABD kamu yönetiminin işletme disiplinine yakın olması ve alanın örgüt kuramları ile istila edilmesine yol açmasının etkili olduğu şeklinde görüşler öne sürülmüştür (Güler, 1994). Nitekim Wilson'un (1887:201-202) kamu yönetimi ile ilgili en önemli yaklaşımı, onu işletme disiplinine yönlendirmesi olmuştur.

Kamu yönetiminin işletme disiplinine ve örgüt kuramlarına yaklaşmasıyla ortaya çıktığı düşünülen bunalıma karşı, Avrupa kamu yönetimi anlayışııın, umumi amme hukuku ve idare hukuku ağırlıklı bir yapıya sahip olduğu ifade edilerek, disiplinin bunalımına çözüm bulunmasında bu özelliklerin önemli olabileceği savunulmuştur (Şaylan, 1996).

Disiplinin Avrupa'daki gelişimi üzerine yapılan çalışmalarla, Wilson öncesi Avrupa kamu yönetiminin Wilson'un görüşleri ile büyük oranda özdeş olduğu anlaşılmıştır. Nitekim kendisinin de belirtildiği gibi, yazar, Fransa ve Almanya'daki çalışmalardan yararlanmış ve orada oluşan kuramı ABD'ye aktarmıştır.

Disiplinin bunalımına, temelde siyaset-yönetim ayrımının neden olduğu Waldo (1968) tarafından ifade edildiği gibi, siyaset biliminden ayrıştııılan kamu yönetiminin örgüt kuramlarına yönelmesi suretiyle sorunun ortaya çıktığı da iddia edilmiştir. Hâlbuki gerek Fransa (Vivien, 1859) ve gerekse Almanya (Bluntschli, 1875) kamu yönetimi yazınında, siyaset - yönetim ayrımı Wilson'dan daha önce ortaya konulmuştur. Bu yönüyle Avrupa ve $A B D$ yaklaşımları özdeş olmakla birlikte, Wilson'da kamu yönetiminin işletme disiplinine yakın olduğu vurgusu bir farklılık ortaya koymaktadır.

Bu çalışmada, kamu yönetiminin kökeninin Avrupa'ya ait olduğu bilgisi çerçevesinde; kamu yönetiminin Fransız öncüleri Bonnin ve Vivien'le ilgili daha önce verilen bilgiler (Karasu, 2004;Çiner, 2009) teyit edilmekte, Prusya kamu yönetimi ekolünün ortaya çıkmasında ismi geçen Seckendorff, Wolff, Hegel ve Lorenz Von Stein'in görüşlerine yer verilmektedir. Prusya ekolü ve bu ekolün en etkili ismi Bluntschli'nin görüşleri Türk alan yazınında ilk defa ortaya konulmaktadır.

\section{KAMU YÖNETIMININ KÖKENINE DAIR}

Kamu yönetimi ile ilgili ilk özel çalışma (German Principality), Seckendorff tarafından 1656'da gerçekleştirilmiş, daha sonra, 1700'lerde konu Delamare tarafından ele alınmıştır (Treatise on Polity). Bu çalışmalar, devlet yönetimi üzerine tarihi, pratik ve yasal bilgiler içermekte ve önemli bir kamu yönetimi içeriğine sahip bulunmamakla birlikte, "kamu yönetimi" etiketli ilk çalışmalar sayılmaktadırlar (Rutgers, 2010a).

Kamu yönetiminin ortaya çıkışına zemin hazırlayan önemli kaynaklardan biri olan Kameralizm, devleti prensin mülkü saymaktadır. Bu yaklaşımda prensin ve devletin menfaatleri birlikte değerlendirilmekte ve birbirinden ayrılmamaktadır (Small, 2001). 1729'da Kameralizm çalışmaları için Prusya'da iki akademisyenin görevlendirilmesi, yönetimin akademik bir disiplin olarak ele alınmasını sağlamıştır (Rutgers, 2010a).

Bundan sonra, Fransız bilim adamı Charles-Jean Bonnin'in 1812 tarihli "Kamu Yönetiminin İlkeleri" adlı 3 ciltlik eseri önemli bir adımı oluşturmuştur. Bu kitap, ilk defa "kamu yönetimi" adıyla yayınlanan bir eser olması yanında, kamu yönetimi ilkelerine sistematik ve kapsamlı biçimde yer veren ilk çalışma olmuştur (Karasu, 2004:3).

Bonnin, kamu yönetimini geniş bir tarzda değerlendirmiş; kişinin toplumla ilişkisinin bilimi olarak ortaya koymuştur. O'na göre, sosyal bir düzeni amaçlayarak, kamu otoritesinin faaliyetleri doğrultusunda bu ilişkinin sürdürülmesi yine kamu yönetiminin kapsamında yer almaktadır. Bu yaklaşım, Bonnin tarafından kamu yönetiminin, sosyal bir olgu ve onun uygulanması biçiminde algılandığını göstermektedir (White,1945:272-273).

Kamu yönetimini daha bilimsel bir disiplin haline getirmeyi amaçlayan Bonnin'in de katkısıla, 19.yüzyılın ilk yarısında bir tür sosyal bilim olarak idare bilimi ortaya çıkmıştır. Pragmatik bir arka plana sahip olan bu öncü Fransız kamu yönetimi yaklaşımı, geleceğin kamu çalışanlarını düzene sokarak devletin etkililiğini artırmayı amaçlamaktaydı. Disiplin; ekonomi, siyaset bilimi, hukuk ve sosyolojiyi de kapsayan geniş bir bilimsel taban oluşturmaya yönelmiştir (Van der Eyden, 2003:7).

Fransız kamu yönetiminin öncülerinden Macarel, 1828-1844 yılları arasında üç idare hukuku kitabı yayınlamıştır. Macarel'in özelliği, o zamana kadar yapıldığı gibi; kamu yönetimini idare hukuku temelinde ele almak yerine, idare hukukunu yönetim ilkeleri bazında incelemiş olmasıdır (Karasu, 2004:4). 
Batı toplumlarında idare ile yargılamanın tek elde toplanması uygulaması mevcuttu ve bunu değiştirmek hiç de kolay olmamıştır. İdarenin güçlü olabilmesi için yargılama yetkisinin bulunması ve bu yetkiyi fiilen kullanması gerektiği görüşü, bir ön kabul durumundaydı. Yargı idaresi ile kamu yönetimi faaliyetinin birbirinden ayrılması, yargıçlara bağımsızlık garantisi verilene kadar, yüz yıllık bir zamana ihtiyaç göstermiştir. Macarel, Cormenin ve Vivien, idari yargılama uygulamalarını eserlerinde tartışmışlardır (Van der Eyden, 2003:568).

1852'de Vivien tarafından yayınlanan "Yönetsel Incelemeler" başlıklı 2 ciltlik çalışma, kamu yönetiminin temel tartışma alanlarında ayrıntılı açıklamalara yer verdiği gibi, siyaset-yönetim ikiliğini de ele almıştır (Karasu, 2004:5).

Kamu yönetimi disiplininin bağımsız bir disiplin olarak ortaya çıkışında ilk dikkati çeken özellik, siyaset biliminden farklılaştırılması çabasıdır. Fransız kamu yönetiminin önemli isimlerinden Vivien, kuvvetler ayrılığı bağlamında konu edilen yasama, yürütme ve yargı erklerinden yürütmeyi; ulusun genel çıkarlarına yönelik olarak "siyasi" ve kamu hizmetlerinin etkili biçimde gerçekleşmesi açısından da "yönetsel" olarak ele almıştır (Martin, 1987). Vivien tarafından, Wilson'un meşhur makalesinden 35 yıl önce siyaset-yönetim ayrımının yapıldığı anlaşılmaktadır.

Alman akademisyen Lorenz Von Stein, 19.yüzyılın ikinci yarısında çağdaş bir yönetim bilimi tasarlamış ve kamu yönetimine diğer bilim dalları arasında özel bir yer vermiştir.

Wilson'un kaynak gösterdiği Alman hukukçu Bluntschli, (2000:409-410) devletin genel yönetimini "siyaset", ayrıntılarla ilgili yönetimi ise "idare" olarak adlandırır. Devletin yürütme veya kendi tabiriyle hükümet ve idare işlevini inceleyen yazar, karar almanın birincil uygulamasının ise ikincil olduğu görüşündedir.

Kamu yönetimi disiplininin kıta Avrupası'nda iki yönde gelişme gösterdiği belirtilmektedir. Bunlardan biri, yaşanmakta olan kapitalist dönüşümü hızlandıracak bir devlet yönetiminin nasıl oluşturulabileceği sorusuna cevap aramakta olan Kameralizm'in etkisidir. Kameralizm'in devlet yönetimini belirleme çabaSı, 18. ve 19. Yüzyıllarda Alman dünyasında uygulamaya dönük bir devlet bilimi oluşmasına yol açmıştır. Bu şekilde rasyonalist bir Alman-Avusturya kamu bürokrasisi ortaya çıkmasına da katkı sağlamıştır (Şaylan, 1996:4).

İkincisi, devlet yönetiminin hukuka bağlı olması gerektiğini öne süren yaklaşımdır. Burada kamu yö- netiminin idare hukuku üzerine bina edilmeye çalışıldığı söylenebilmektedir (Şaylan, 2000:8). Böylece Avrupa kamu yönetiminin; hukuk ağırlıklı olma ve rasyonalist bir bürokrasi oluşturma yönlerinde gelişim gösterdiği ifade edilmiş olmaktadır.

\section{ABD KAMU YÖNETIMI VE WILSON}

Avrupa'da Vivien ve Bluntschli gibi akademisyenlerin önemli çalışmalarından sonra, kamu yönetiminin okyanus ötesine geçtiği bilinmektedir (Rutgers, 2010a). Woodrow Wilson'un 1887 tarihli "The Study of Administration" ve Frank Goodnow'un 1900 tarihli "Politics and Administration" adlı eserleri, ABD kamu yönetiminin ilk önemli çalışmaları sayılmaktadır.

Nabatchi vd. (2011:i36) ve Van Riper'in (1983) çalışmalarında, 1940'lı yıllara kadar Wilson'un kamu yönetimi disiplininin kurucu babası olduğunun tartışmasız kabul edildiği belirtilmekte, Waldo'nun (1948:79) ise kamu yönetiminin babası olarak Goodnow'u öne sürdüğü ifade edilmektedir.

Sonraki pek çok çalışmada, Wilson'un (1887) yer verdiği siyaset-yönetim ayrımı, kamu yönetiminin bağımsız bir disiplin olarak ortaya çıkmasına işaret sayılmış ve disiplinin başlangıcı olarak Wilson kabul edilmiştir (Martin, 1988:631;Nabatchi, 2009:588;Güler, 1994:9;Şaylan, 2000:7;Karasu, 2004:1). Ancak, bu görüşün yaygınlığı, doğru olduğu anlamına gelmemektedir.

Nitekim Martin (1988), "Woodrow Wilson'un SoIan Mirası" başlıklı makalesinde, başta siyaset-yönetim ayrımı olmak üzere, kamu yönetimi disiplininin doğuşunda Wilson'a atfedilen birçok görüşün, gerçekte Avrupa'da ortaya konulmuş yaklaşımlar olduğunu ifade etmektedir. Buna göre, Amerikan kamu yönetimi yaklaşımı olarak bilinen pek çok şey, gerçekte Avrupa kamu yönetiminden aktarmadır.

Gerek Fransız bilim adamları (örneğin Vivien) gerekse Alman meslektaşları (örneğin Bluntschli), kamu yönetiminin siyaset biliminden ve hukuktan ayrı olduğunu belirtmişlerdir. Wilson ise (1887:198-209), bunlara ilave olarak, kamu yönetimi alanının siyaset biliminin bir meyvesi olduğunu ama aynı zamanda bir işletme yönetimi alanı olduğunu (the field of administration is a field of business ) ifade etmiştir.

Wilson ayrıca (1887:201), "örgütünü güçlendirmesi ve saflaştırması, görevini yüksek görev duygusuyla taçlandırabilmesi için," kamu yönetiminin; "işletme yönetimi dışındaki her şeyden uzaklaşması" gerektiğini savunmakta ve onu işletme yönetimiyle özdeş gördüğünü ifade etmiş olmaktadır. Wilson'un bu görüşü seslendirdiği orijinal İngilizce ifadesi; "to make 
its business less unbusinesslike" (işini daha az işletme dışındakiler gibi yapma) şeklinde olduğu halde, N. Abadan çevirisinde (Wilson, 1961) hatalı olarak; "işlerini özel teşebbüsten farklı kılacak" biçiminde verilmiştir. Hâlbuki yazar, kamu yönetiminin işletme (veya özel teşebbüs) dışındakilerden farklılaşmasından bahsetmektedir.

Amerikan kamu yönetiminin Fransız kökenli olduğu (Martin, 1987, Karasu, 2004) iddialarına karşılık, $A B D$ kamu yönetiminin öncüsü sayılması gereken Wilson, Alman Bluntschli'den yararlandığını bizzat ifade etmektedir. Buna ilave olarak, Wilson'un Alman devlet kuramcıları Hegel ve Bluntschli'yi okuyarak görüşlerini oluşturduğu belirtilmekte, Johns Hopkins Universitesi'nde doktora yapan Wilson'un, burada Alman Richard T. Ely'den etkilendiği de tespit edilmektedir (Pestritto, 2007).

Johns Hopkins Üniversitesi'nde 11 yıl görev yapan Richard T. Ely'nin Woodrow Wilson'un en önde gelen hocası olduğu belirtilmektedir. Politik ekonomi hocası olan Ely, Alman tarih ekolüne mensuptur ve devleti yaşayan bir organizma olarak görmektedir. Ely'nin bu devlet görüşü Hegel'e ve Bluntschli'ye dayanmaktadır (Thies ve Pecquet, 2010).

Wilson'un kendisinin hiçbir zaman ifade etmediği halde, kamu yönetimi disiplininin kurucusu olarak yazında yer alması, gelinen noktada revize edilmesi gereken bir görüş olarak belirginleşmiştir. Ancak Wilson, disiplinin genel kurucusu unvanını kaybederken, ABD kamu yönetiminin kurucusu unvanını korumaktadır. Ayrıca, kamu yönetiminin işletme disiplini ile özdeş olduğu vurgusu da ilk defa kendisi tarafından ortaya konulmuştur.

\section{KAMU YÖNETIMINDE PRUSYA EKOLÜ}

Kamu yönetimi konularına değinen ilk çalışma, Veit Ludwig von Seckendorff (1626-1692) tarafından 1656 'da yayınlanan Alman Prensliği'dir. Bu kitapta idare ile ilgili konuları küçük bir prenslik düzeyinde ele alan Seckendorff, günlük sorunların ve yerel uygulamaların ötesine geçmeyi hedeflemiştir (Rutgers, 2010a:7). Bir küçük devletin "kullanma talimatı" olarak nitelendirilen Alman Prensliği; tarih, nüfus, ekonomi, okul sistemleri, kanun ve adaletin yanında idare bilimine de yer vermiştir. Devleti bütünsel bir organizma olarak gören Seckendorff, "ortak refah"ın ancak bu bütünsellikle anlaşılabileceği kanaatindedir. Daha sonra "kameral bilim" düşüncesini oluşturan pek çok unsura Seckendorff'ta rastlanmaktadır (Reinert, 2005:226).
Kamu yönetimine kaynaklık eden akımlardan biri olan Kameralizm, devleti kendi mülkü olan ve bir prens tarafından yönetilen büyük bir aile gibi düşünmekte, bu yaklaşımda prensin ve devletin menfaatleri birbirinden ayrılmamaktaydı (Small, 2001). Bu basit yaklaşımına rağmen Kameralizm, devlet yönetimiyle ilgili önemli gelişmelere kaynaklık etmiştir. Özellikle 1729 'da Kameralizm çalışmaları için Prusya'da iki akademisyenin görevlendirilmesi önemli görülmektedir. Kameralizmin resmen kabulü ve kurumlaşması anlamına gelen bu olaydan birkaç on yıl sonra, bütün orta Avrupa üniversitelerinde bu konuda çalışmalara başlanmış ve kameral bilim ekolü oluşmuştur (Rutgers, 2010a).

Kameral bilim anlayışının hâkim olduğu dönemde yaşayan Christian von Wolff (1679-1754), bu anlayışa önemli katkılarda bulunmuştur. Wolff'a göre "ortak iyi" ve "barış" devlet yönetiminin en önemli hedefini oluşturur. Bu hedefe ulaşılabilmesi için idarenin adalet ve yarar gözeterek hareket etmesi gereklidir (Rutgers, 2010b:9). Yönetim düşüncesinin gelişiminde mutluluk devleti kavramını kullanan ilk yazar olarak Wolff, kamu yönetimini vatandaşların mutluluğu olarak anlamlandırmıştır.

Rutgers (2010b:1,2), Wolff'un kameralizm için felsefi bir başlangıç ve ayrılış anlamına geldiğini belirtmektedir. Wolff'un kameralizm felsefesi, kamu yönetimini en ön sıraya koymuştur. Wolff'a göre, devlet ve toplum birbirine karşı kutuplar değildir ve aksine birliktelikleri söz konusudur. Devleti aileye benzeten yazara göre; aile bireylerinin birbirlerini mutlu etmek için çalışmaları bir "ortak refah" oluşturur. Ortak refah ise devleti oluşturur. Ona göre insan davranışları gibi devlet de doğa yasasına dayanır. Bir devletin temeli, çağdaşlarının düşüncelerine dayanır. Birey özgürlüğünü isterse, devlet de bireyi düşünür ve refah devleti olarak bireyin özgürlüğünü ve mutluluğunu sağlar. Devletin amacına hizmet etmeyen yönetimi ise eleştirmektedir (Rutgers, 2010b:8).

Devletin bireyin refahını güvenceye almasını savunan Wolff, bunun vatandaşa otomatik bir biçimde refah sağlama anlamına gelmediğini; onu çalışmaya sevk etmesi gerektiğini savunmaktadır (Reinert, 1999:280). Devlet müdahalesi, Wolff'a göre; kamu sağlığı, fakirlerin korunması ve yardım kuruluşları olmak üzere üç alanı düzenlemelidir. Bu ise karmaşık bir yasal ağ yapısı oluşturulmasını gerektirmektedir (Rutgers, 2010b:9).

Devleti ahlaki idenin gerçekleşmesi olarak alan ve kutsayan Friedrich Hegel (1770-1831), genel iradenin somut biçimde devlette ortaya çıktığını savunmakta- 
dır. Devletteki genel irade ile bireyin iradesi arasında tam bir uyum vardır. Benzersiz ve üstün olan devlet, bireyleri de kapsamaktadır (Agbude, 2011:118). Hegel'in devlet felsefesinin başlangıç noktası özgürlüktür. Ancak bu özgürlük bireyselliği öne çıkarmamakta, üyesi olduğu toplum içinde bireyi konumlandırmaktadır. Ait olduğu toplumun yasa ve gelenekleri arasında, bireyin duygu ve düşüncede özgür olması anlamına gelmektedir (Hobhouse, 1999:22-23).

Hegel'in devlet anlayışı, yoksullukla sistematik ve genel bir mücadeleyi öngörmekte, ama bununla yetinmemekte; zayıfların modern toplumun entelektüel kazanımlarından ve siyasi özgürlüklerden de yararlandırımalarını istemektedir (Ferraro ve Ajenjo, 2007:4). Devletin topluma ve bireye dönük yükümlülüklerini yerine getirmesi, ancak kamu yönetimi ile mümkün olabilecek bir olgu olmakla birlikte, Hegel bu noktadan ileriye gitmemektedir. Bu sebeple Hegel'in devlet ve toplumla ilgili bu görüşleri, ancak Lorenz von Stein'in çalışmalarıyla kamu yönetimi disiplini incelemelerine dâhil olabilmiştir (Rutgers, 2010a:18).

Bir başka Prusyalı Lorenz Von Stein (1815-1890) 19. Yüzyılın ikinci yarısında ilk çalışmaları yapan öncülerden sayılmaktadır. Kamu yönetiminin diğer bütün bilimlerin tacı olduğunu ve onları birleştirdiğini beyan eden Stein, bunun nedenini; kamu yönetiminin vatandaşların özgürlüğünü garanti etmek için, bütün insan bilgisini kullanması gerektiği biçiminde açıklamaktadır (Rutgers, 2010a:8). Stein'in devlet anlayışı açık biçimde Hegel'e dayanmakta, ama onun görüşlerini daha ileriye götürerek kamu yönetimi bakımından önemli kavramlaştırmalara gitmektedir. Bunlar arasında devleti; "anayasa" ve "idare" olmak üzere iki bileşene ayırması önemlidir. Ona göre anayasa tarafından yasal güvence altına alınan bireyin siyasi özgürlüğü, olumsuz gelişmelere karşı "sosyal devlet idaresi" tarafından da korunmalıdır. Stein'in kamu yönetimi ve sosyal devletle ilgili bu görüşleri XIX. Yüzyıl boyunca hem Avrupa'da hem de Amerika'da önemli etkiler meydana getirmiştir (Ferraro ve Ajenjo, 2007:4-5). Stein, Pek çok araştırmacı tarafından (Thornhill, 2006:794; Lodhi ve Mikulecky, 2010:104; Thornhill ve Dijk, 2010:99), Avrupa'da kamu yönetiminin kurucusu sayılmaktadır.

Yenilikçi bir yaklaşıma sahip olan Lorenz Von Stein, aşağıdaki görüşleri ortaya koymuştur:

- Kamu yönetimi bilimi, sosyoloji, politik bilim ve kamu finansmanı gibi pek çok disiplinin erime potasidır (melting pot).

• Kamu yönetimi entegre (bütünleşmiş) bir bilimdir.
- Kamu yönetimi bir kuram olmakla birlikte, kuramla uygulama arasında etkileşim gereklidir ve temeli kuram oluşturmaktadır.

- Kamu yönetimi bilimsel bir yöntem geliştirmeye çalışmalıdır (Thornhill, 2006:794).

Stein'den sonra, Alman kamu yönetimine en önemli katkıуı Johann Caspar Bluntschli (1808 1881) sağlamaktadır. Bluntschli'nin katkısı, Wilson'un ünlü makalesinde kendisini kaynak göstermesiyle açıklık kazanmış olmaktadır. Wilson (1877:209-210), kamu yönetiminin siyasetten ve anayasa hukukundan ayrı olduğunu ifade ettikten sonra, idarenin alanının siyasetten ayrı olduğunu ve yönetim sorularının siyasi sorulardan farklı olduğunu beyan etmektedir. Buna göre siyaset kamu yönetimi için görevler belirleyecektir, ama yönetim birimlerini manipüle etmeyecektir. Wilson bunu ifade ettikten sonra, bu ayrımın alanın yüksek otoriteleri olan Alman yazarlara ait olduğunu bildirmekte, Bluntschli'nin Politik adlı eserine atıf yapmakta ve bu eserde kamu yönetiminin hem siyasetten hem de hukuktan ayrılması gerektiğinin belirtildiğini ifade etmektedir.

Bluntschli'nin "Politik" adını taşıyan tek kitabı; "Geschichte des algemeinen Staatsrechts und der Politik" adlı eseridir. Ancak Arthur S. Link (1968:431), Wilson'un atıf yaptığı eserin bu olmadığını; Bluntschli'nin "Bilim olarak Siyaset" (Politik als Wisselschaft) adını taşıyan, "The Theory of the State" adlı büyük eserinin üçüncü cildi olduğunu belirtmektedir.

Büyük ölçüde anayasa hukuku ve uluslararası hukuk alanlarında çalışan Bluntschli'nin, "organik devlet kuramı" ünlüdür. Bluntschli (1875:1-3) organik devlet kuramıyla, devletin bütünü ve parçaları arasında uyum olmasını öngörmektedir. Almanlar olarak, devleti daha iyi anlamak için kamu hukuku ve siyaset bilimi biçiminde ikiye ayırıp incelediklerini, bunların yanında; uluslararası hukuk, idare (kamu yönetimi), güvenlik ve politik istatistik gibi pek çok branşı ortaya koyduklarını belirtmektedir.

Bluntschli'nin (1875:24-25) "organik devlet" düşüncesine göre, devlet ölü bir makine veya cansız bir araç değildir. Siyaset bilimcilerin görmezden geldiği devletin organik doğasını, Alman tarih hukukçuları ekolu kabul etmiştir. Bu yaklaşım devletin matematik veya mekanik izahını kabul etmediği gibi, atomistik bir yapıda olduğunu da yadsır. Atomistik yaklaşımların bireylerin bütünlüğünü göz ardı ettiğini belirten Bluntschli, devletin dolaylı olarak insan ürünü olduğunu, doğal bir organizma olmadığını ama doğal organizmaların kopyası olduğunu iddia etmektedir. Bluntschli'ye göre bir organizmanın başlıca üç öğesi 
mevcuttur. Bunlar; ruh ve bedenin birliğiyle oluşması, bir bütün olmakla birlikte üyeleri olan parçalara sahip olması ve dışa doğru büyümesidir. Yazar'a göre her üç özellik de devlette mevcuttur.

Bodin'in prensin yargılama yapmaması gerektiğini ve bu işi bağımsız mahkemelere bırakması gerektiğini söyleyen ilk kişi olduğunu belirten Bluntschli (1875:405,406), Montesquieu'nun ise sivil özgürlük ve güvenlik için, yasama, yürütme ve yargılama işlerinin ayrı birimlerce yapılmasını öngördüğünü belirtmektedir.

Montesquieu'nun yasama, yürütme ve yargı üçlemesini inceleyen Bluntschli, kamu yönetiminin devlet içinde ayrı ve özel bir yere sahip olduğunu belirtmektedir. O'na göre, sadece etkili bir dördüncü güç devlet iradesini tamamlayabilir, yerine getirebilir ve toplumun refahını artırabilir. Bu güç, kamu yönetimidir. Bluntschli, kamu yönetimini "toplumsal arzu"nun koruyucusu olarak görmüştür. Kamu yönetimi kuramını; anayasa-idare, yasama-yürütme ve siyaset-yönetim dikotomilerini kullanarak incelemiş ve geliştirmiştir. Bluntschli, "siyaset idarenin yardımı olmadan hiçbir şey yapamaz" demek suretiyle, kamu yönetiminin siyaset bilimi açısından önemini gözler önüne sermiştir. $O$, kamu yönetimini pasif bir idare aracı olarak değil, devletin etkili bir organı olarak değerlendirmiştir (Rosser, 2011).

Bluntschli (1875:408), Bodin ve Montesquieu'nın kavramlaştırmalarına atıf yaptıktan sonra, kendisinin ortaya attığı organik devlet kuramıyla kuvvetler ayrımını uyumlaştırmaya çalışmıştır. Ona göre, bir insanın vücudunda bulunan çeşitli organlar nasıl farklı işlevler görüyorsa, devlette de her işlevi farklı organlar görmelidir. Bu ayrımın "kuvvetler ayrıı̆ı" biçiminde ifadesine karşı çıkan yazar, doğru bir konunun yanIış isimlendirilmiş olduğunu, bu organların ayrılma kadar bir bedenin organları gibi birleşmelerinin de gerekli olduğunu vurgulamaktadır.

Kuvvetler ayrımı ile ortaya konulan "yürütme kuvveti", Bluntschli'ye göre (1875:410) iki işlevi birlikte içermektedir. Bunlardan biri karar alma ve emir vermeyi içeren hükümet işlevi olup, yazar tarafından "birincil" işlev olarak nitelendirilmektedir. Hükümet karar verir, çözümün ne olduğunu gösterir, dileğini ve arzusunu ortaya koyar, kısaca emreder ve yasaklar. Hükümetin emirleri, "ikincil" işlev olarak alttaki resmi makamlar tarafından yerine getirilir. Bluntschli'nin anlatımında "birincil" olarak nitelenen karar alma ve yön belirleme işlevi siyasete, "ikincil" olarak adlandırılan kararları uygulama işlevi ise kamu yönetimine karşılık gelmektedir.
Bluntschli (1875:410-412), genel devlet yönetiminin siyasi yönetim olduğunu, idarenin ise ayrıntılarla ilgilendiğini belirtmiştir. Yine pek çok kamu kuruluşunun hükümet gücü kullanılmadan; bilimsel ve teknik bir anlayışla, toplumun özgürlüğü, refahı ve menfaatine göre yönetildiğini savunmaktadır. Buna göre kamu yönetimi, bilimsel ve teknik bir anlayışla ve toplumun özgürlüğü, refahı ve yararı önde tutularak yerine getirilmekte ve genel devlet yönetimi olarak tanımlanan siyasetten ayrılmaktadır.

Siyaset-yönetim ayrımı ile ilgili görüşlerinin Bluntschli'ye dayanmakta olduğunu ifade eden Wilson (1877:210-211), kamu yönetimini siyaset ve hukuktan ayıran Bluntschli'nin görüşlerine de yer vermiştir. Bluntschli'ye atıf yapan Wilson, yazarın siyasetin "büyük ve evrensel" konular için olduğunu, kamu yönetiminin ise, "bireysel ve küçük" konularla ilgili devlet faaliyetlerini ele aldığını belirttiğini ifade etmektedir. Böylece siyaset devlet adamının faaliyet alanı iken, yönetim teknik memurların işi olmaktadır.

Wilson'u etkileyen Alman kuramcılar arasında en önde geleni, kamu yönetimi üzerinde daha fazla duran ve önemli görüşler geliştiren Bluntschli olmuştur. Bluntschli, bürokrasinin aşırı güçlenmesini ve politikleşmesini riskli bulmaktadır. Bürokrasi kavramını aşağılayıcı tonda kullanan yazar, bürokrasiyi, toplumsal ihtiyaçların objektif biçimde tatminine karşı, teknik bilginin ve biçimselliğin egemenliğinde görmektedir. Siyasetin kamu yönetiminin dışında kalması için, üst düzey kamu yöneticilerinin siyasi eğilimli olmalarını ve göreve gelen siyasetçilerle gelip, onlarla birlikte ayrılmalarını da uygun görmektedir (Rosser, 2011). Bürokrasinin politize olmasına karşı bir tedbir olarak savunulan ve Türkiye'de de zaman zaman gündeme gelen bu yaklaşımın Bluntschli tarafından 1875'te ifade edilmiş olması ilginçtir.

Bluntschli (1875:414-416), kamu hizmeti kavramını incelemiş ve bu konuda yeni görüşler geliştirmiştir. Ona göre devletin mecbur ettiği veya devlet için gönüllü yapılan; birincil veya ikincil bütün hizmetler kamu hizmetidir. Dini kurumlar ve diğer topluluklar da topluma hizmet verirler ve yaptıkları kamu hizmetidir, ama bunlar devlete bağlı hizmetler değildir. Bütün kamu hizmetleri dar anlamda kamunun işlevlerine dâhil olmayabilir ve bütün kamu hizmeti görenler de devlet memuru değildir. Yazar, devlet işlevi görenleri; devlet çalışanları ve yardımcıları biçiminde ikiye ayırarak incelemektedir.

Devlet memurlarının atanmaları ile ilgili olarak profesyonel görev yapanlarla diğer memurları birbirinden ayırmaktadır. Modern devlet için önemli 
gördüğü profesyonel görevlerin teknik bilgiye dayalı olması nedeniyle, atanmaları için eğitim ve adaylık sürecine ihtiyaç olduğunu belirtmektedir. Ortaçağ'da yaygın olan miras yoluyla devredilen devlet görevlerinin modern anlayışa uygun olmadığını belirtmekte, bunun dışında profesyonel ve onursal görevlerin söz konusu olabileceğini ifade etmektedir (Bluntschli, 1875:417-421).

Kamu görevlilerinin hak ve ödevlerini inceleyen Bluntschli (1875:422-426), görev alanıyla ilgili hizmetleri yerine getirmek, emirlere uymak, verilen unvanları kullanmak ve hak ettiği ücreti almak gibi hak ve ödevlere yer verdikten sonra, görev disiplinine vurgu yapmaktadır.

Bluntschli (1875:427-430), kamu hizmetinin sona ermesini de incelemekte, kamu görevlerinin kişilere bağlı olmadığını, devletin devamlılığı sebebiyle kişilerle bağlı olmaksızın hizmetlerin devam etmesi gerektiğini belirtmektedir. Kamu görevi alıp almamanın ve istifa etmenin kişilerin tercihine bağlı olduğunu, ama görev aldıktan sonra aldıkları görevi yerine getirmekle görevli olduklarını, kamu hizmetini aksatamayacaklarını beyan etmektedir.

Prusya ekolü olarak nitelendirilen Alman kamu yönetimi anlayışının gelişiminde; Alman tarih ekolüne dayalı yaklaşımların egemen olduğu ve organik devlet anlayışının bu yaklaşımların bir sonucu olarak ortaya çıktığı anlaşılmaktadır. Alman kamu yönetiminin gelişiminde Lorenz Von Stein ve Bluntschli'nin çalışmaları önemli görülmektedir. Özellikle Bluntschli'nin kamu yönetiminin hukuktan ve siyaset biliminden ayrı olarak ele alınmasında önemli katkıları olduğu anlaşılmaktadır. Bluntschli'nin kamu hizmeti kavramını ele alması yanında, kamu görevlerinin yerine getirilmesini incelemesi, kamu görevlilerinin görev ve sorumluluklarına yer vermesi önemli görülmektedir.

\section{SONUÇ}

Almanya'da ortaya çıkan Kameralizm, kamu yönetimi disiplinine kaynaklık eden önemli bir yaklaşım olmuştur. Kameralizmin devleti bir bütün olarak ve prensin sahibi olduğu bir mülk olarak ele alışından sonra, kamu yönetimini bir bilim olarak ele alan Lorenz von Stein olmuştur. Stein bu sebeple, Avrupa kamu yönetiminin kurucusu sayılmaktadır. Ancak Stein'in kamu yönetimi algısı, onu diğer disiplinlerden ayırmayı değil, diğer disiplinlerle birleştirerek bütüncü bir yaklaşıma ulaşmayı ilke edinmiştir.

Kamu yönetiminin siyaset biliminden ayrılarak, ayrı bir disiplin olarak gelişiminin kökeni 1877 önce- sine gitmekte, Fransız Vivien ve Alman Bluntschli'ye dayanmaktadır. Bluntschli'nin Alman tarih ekolüne mensup bir akademisyen olarak "organik devlet" görüşüne sahip olması, devletin bütünsel olarak ele alınmasını gerektirmiştir. Devleti canlı bir organizmaya benzeten organik devlet anlayışı, onun kamu yönetiminin hukuktan ve siyaset biliminden farklı olduğunu görmesini engellememiştir.

Bunun yanında, kamu hizmeti kavramını ele alması, kamu görevlileri ile ilgili konulara özel yer vermesi önemli olmuştur. Ayrıca, 1980'lerde liberal söylemin bir parçası olarak gelişen bürokrasi eleştirilerinin, $1875^{\prime}$ te Bluntschli tarafından ifade edilmiş olması, kamu yönetimi anlayışının kökeninde liberal özellikler taşıdığı biçiminde yorumlanabilecektir.

Avrupa kamu yönetiminin kuvvetler ayrılığı ilkesini esas aldığı, yürütme kuvvetinin ise siyaset ve yönetim olarak ikiye ayrıldığı anlaşılmaktadır. Siyasetin alanı; Bluntschli'ye (1875) göre; "genel devlet yönetimi" yahut "büyük ve evrensel konular" iken, Vivien'e göre "ulusun genel çıkarının kollanması"dır (Martin, 1987). Her iki ifadenin bir ölçüde özdeş olduğu ve siyasetin tanımında her iki akademisyenin birbirine yakın durduğu söylenebilecektir.

Bluntschli'nin (1875), bir yandan kamu yönetiminin görev alanının; "ayrıntılar" veya "küçük ve bireysel konular" olduğunu söylerken, diğer yandan "kamu yönetimi olmadan siyasetin hiçbir şey yapamayacağını" belirtmesi tenakuz olarak değerlendirilebilir. Yazarın kamu yönetimini pasif konumda görmek istemediği ve önemli bir alan olarak gördüğü yazılarında açık biçimde mevcuttur. Hatta kuvvetler ayrımı bahsinde, kamu yönetimini dördüncü kuvvet olarak nitelediğine yukarıda değinilmiştir.

Kamu yönetimi disiplininin Wilson öncesi dönemde Prusya'da hangi özelliklere sahip olduğu böylece ortaya konulmakta, alanının öncü yazarlarının ne tür görüşlerle disiplinin temelini attıkları bir ölçüde açıklığa kavuşmuş olmaktadır.

Bir dönem kabul edildiği gibi, kamu yönetiminin kökeninin Amerikan ve kurucusunun Wilson olmadığı, daha önce konu ile ilgili yapılan tespitlere dayalı olarak ortaya konulmuştur. Ancak Wilson'un ABD kamu yönetiminin kurucusu olduğu kabul edilmelidir. Disiplinin siyaset biliminden ayrışarak varlık alanına girdiği düşünüldüğünde, siyaset-yönetim ayrımının Fransız Vivien (1859) ve Alman Bluntschli (1875)'de mevcut olduğu anlaşıldığından, disiplinin kökeninin Avrupa olduğu kesin biçimde söylenebilmektedir. 
Fransız Bonnin ve Vivien'in kamu yönetiminin ortaya çıkışına kaynaklık ettiği varsayılan görüşleri daha önce Türk alan yazınında yer almıştır. Ancak, Bluntschli'nin kamu yönetimine kaynaklık eden görüşleri ve Wilson'un görüşlerinin Alman tarih ekolüne ve Bluntschli'ye dayandığı hususları, ilk defa bu makalede ele alınmış olmaktadır. Amerikan kamu yönetiminin kurucusunun Wilson olduğu ve kamu yönetimini işletme yönetimi ile özdeşleştiren görüşlerin de ilk defa kendisi tarafından ortaya atıldığı anlaşılmaktadır. 


\section{KAYNAKLAR}

Agbude, G.A. (2011) "The Hegelian State and The Rise of The Tyranny of The Minority: The African Poitical Experiment" Journal of Sustainable Development in Africa, 13(3):114-131.

Bluntschli, J.C. (1875) The Theory of the State, Oxford, London, Clarendon Press.

Çiner, C.U. (2009) "Fransız Yönetim Biliminin Gelişimi: Polis Biliminden Örgüt Bilimine" Amme İdaresi Dergisi, 42(1):1-22.

Ferraro, A. ve Ajenjo, N. (2007) "A Positive Ethics for Public Administration: Altruism, Self-Interest and the Concept of the State" http://www.law.kuleuven. be/integriteit/egpa/previous-egpa-conferences/ madrid-2007/ferraro.pdf, (13.11.2011)

Güler, B. (1994) "Nesnesini Arayan Disiplin:Kamu Yönetimi” Amme İdaresi Dergisi, 27(4):1-19.

Goodnow, F. (1900) Politics and Administration: A Study in Government, New York, The Macmillan Company.

Hobhouse, L.T. (1999) The Metaphysical Theory of the State: A Criticism, Canada, Batoche Books.

Karasu, K. (2004) "Kamu Yönetimi Disiplininin Kökenine İlişkin Bir Not” http://kamyon.politics.ankara. edu.tr/bulten/belgeler/04.pdf, (14.07.2011)

Keskin, N.E. (2006) “Türkiye’de Kamu Yönetimi Disiplininin Köken Sorunu" Amme İdaresi Dergisi, 39(2):1-28.

Link, A.S. (1968) "Woodrow Wilson and the Study of Administration" American Philosophical Society, 112(6):431-433.

Lodhi, M.S. ve Mikulecky, P. (2010) "Knowledge Management Implementation in Public Services" International Conference on Communication and Management in Technological Innovation and Academic Globalization, Novemver 30-December 2.

Martin, D.W. (1988) "The Fading Legacy of Woodrow Wilson" Public Administration Review, 48(2):631-636.

Nabatchi, T. (2009) "Radical Individualism, Instrumental Rationality, and Public Administration: A Paper Formerly Titled 'Roofied and Rolled'" Public Performance \& Management Review, 32(4):585-591.

Nabatchi, T. Goerdel, H.T. ve Peffer, S. (2011) "Public Administration in Dark Times: Some Questions for the Future of the Field" Journal of Public Administration Research and Theory; Minnowbrokk III, 21(1):i29-i43.
Pestritto, R.J. (2007) "The Birth of the Administrative State: Where It Came From and What It Means for Limited Government” First Principles Series, 16:1-16.

Pestritto, R.J. (2005) Woodrow Wilson and The Roots of Modern Liberalism, Rowman \& Littlefield Publisher Inc.

Reinert, E.S. (2005) "A Brief Introduction to Veit Ludwig von Seckendorff (1626-1692)” European Journal of Law and Economics, 19:221-230.

Reinert, E.S. (1999) "The Role of The State in Economic Growth" Journal of Economic Studies, 26(4/5):268-326.

Rosser, C. (2011) "Johann Caspar Bluntschl's Organic Theory of State and Public Administration" http://www. irspm2010.com/workshops/papers/16_johanncaspar. pdf, (10.08.2011)

Rutgers, M.R. (2000) "Public Administration and the Separation of Powers in a Cross-Atlantic Perspective" Administrative Theory \& Praxis, 22(2):287-308.

Rutgers, M.R. (2010a) "Theory and Scope of Public Administration: An Introduction to the Study's Epistemology" Public Administration Review, Foundations of Public Administration Series, 1-45.

Rutgers, M.R. (2010b) “Chistiaan Von Wolff (16791754) as Cameralistic Philosopher" The Crisis: Challenges for Public Management, University of Berne, Centre of Competence for Public Management, 7-9 April 2010.

Şaylan, G. (1996) "Bağımsız Bir Disiplin Olarak Kamu Yönetimi:Yeni Paradigma Arayışları” Amme İdaresi Dergisi, 29(3):3-16.

Şaylan, G. (2000) "Kamu Yönetimi Disiplininde Bunalım ve Yeni Açılımlar Üzerine Düşünceler” Amme Ídaresi Dergisi, 33(2):1-22.

Small, A.W. (2001) The Cameralists: The Pioneeers of German Social Polity, Batoche Books, Kitchener-Ontario

Thies, C. F. ve Pecquet, G.M. (2010) “The Shaping of a Future President's Economic Thought: Richard T. Ely and Woodrow Wilson at 'The Hopkins'" Independent Review, 15(2):257-277.

Thornhill, C. (2006) "The Domain of Public Administration" Journal of Public Administration, 41(4):793-806.

Thornhill C. ve van Dijk G. (2010) "Public Administration Theory: Justification for Conceptualisation" Journal of Public Administration, 45(1):95-110. 
Van der Eyden, T. (2003) Public Management of Society: Rediscovering French Institutional Engineering in The European Context, IOS Press.

Van Riper, P.P. (1983) “The American Administrative State: Wilson and The Founders-An Unorthodox View" Public Administration Review, 43:477-90.

Waldo, D. (1948) The Administrative State: A Study of The Political Theory of Public Administration, New York, Ronald.

Waldo, D. (1968) "Scope of the Theory of Public Administration" Charlesworth et al (eds.) Theory and Practice of Public Administration: Scope, Objectives, and Methods, Philadelphia, The American Academy of Political and Social Science.

White, L.D. (1945) “The Just Official” Public Administration Review, 272-274.

Wilson, W. (1887) "The Study of Administration" Political Science Quarterly, 7(2):197-222.

Wilson, W. (1961) "İdarenin İncelenmesi” Woodrow Wilson Seçme Parçalar, İstanbul, Türk Siyasi İlimler Derneği Yayını. 